Prause Gunnar,

Dr.Sc., Professor, Tallinn University of Technology, Estonia;

Wismar Business School, Wismar University, Germany

Hoffmann Thomas,

Dr.Sc., Professor, Tallinn University of Technology, Estonia

\title{
INNOVATIVE MANAGEMENT OF COMMON-POOL RESOURCES BY SMART CONTRACTS
}

Abstract. The access to common-pool resources, i.e. to resources in limited common property, are legally distributed in a far more diverse way than limited private property resources. In transportation, a critical case for common-pool resources appear in Green Transport Corridors (GTC), that has been coined by European Union as being «sustainable logistics solutions for cargo transportation' with a shared pool of resources aiming for multimodal trans-shipment routes with a concentration of freight traffic between significant hubs». Although there are already existing implementations of GTC concepts, there are still a lot of open questions concerning GTC governance and ownership models hindering easy marketing of the GTC approach. This paper discusses how and to which extent smart contracts in combination with blockchain technology as innovative solutions are able to facilitate GTC governance and how smart contracts can be applied to provide legal certainty by managing and allocating distributed access to common-pool resources. Smart contracts can be considered as computerised transaction protocols for the execution of underlying legal contracts, and they do not only target reducing transaction costs by realising trackable and irreversible transactions through blockchain technology for distributed databases, but also show high potential to strengthen cooperative business structures and to facilitate the entrepreneurial collaboration of cross-organisational business processes. From a legal perspective, it is controversial whether the use of smart contracts to distribute access to resources in terms of both general common-pool resources. GTCs implies an added value automatically for legal certainty and fair balance among different forms and degrees of access granted to different members of the cooperative. In cases of incorrect performance, change of circumstances or unduly induced contracts smart contracts fall considerably short on the protection of weaker parties, which the paper illustrates at the example of GTCs to be a decisive detriment of the cooperative members. The paper analyses these potentials and risks of smart contracts for the case of GTCs and showcases from both business and legal perspective in terms of their potential as viable means of distributing access to common-pool resources comprising infrastructure.

Keywords: common-pool resources, cooperative governance, blockchain, smart contracts, Green Transport Corridors.

Introduction. In the year 2009, the Nobel Prize Committee awarded the in the prize of Economic Sciences to Elinor Claire Ostrom for her investigations about the «analysis of economic governance, especially the commons", in which she analysed a variety of communities around the world in how they manage shared pool finite resources (common property resources) of natural and human-made origin. She pointed out that private property is not the only concept of protecting finite resources from ruin or depletion, and she documented how communities devise ways to govern sustainable commons for generations.

However, the methods from both legal and business management perspective remain yet to be specified. The issue has been approached by the EU from an entirely different angle as far as the ecofriendly management of limited common-pool resources in terms of transport infrastructure is concerned: reacting initially mainly to the estimated growth of passenger and freight transport in the European Union, the European Commission presented between 2001 and 2011 a serious of White Papers setting a political framework for the EU transport policy development for the next decades. (COM 2007, 2011) A common aim of all White Papers on transport was the necessity to shift significant cargo volumes away from the dominant road traffic to greener transport modes, i.e. trying to implement more environmentally friendly and safer transport by reducing accidents, congestions and pollution.

Cite as: Prause, G., Hoffmann., T. (2020). Innovative Management of Common-Pool Resources by Smart Contracts. Marketing and Management of Innovations, 1, 265-275. http://doi.org/10.21272/mmi.2020.1$\underline{22}$ 
In 2007, the European Commission introduced Green Transport Corridor (GTC) concept as «an integrated transport concept where short sea shipping, rail, inland waterways and road complement each other to enable the choice of environmentally friendly transport». These first steps were further specified between 2009 and 2011 by the European Green Paper on TEN-T, the TEN-T Policy Review and as well by the EU White Paper for sustainable transport. Main motivations behind all these political declarations of intent were the increase of European independence from oil imports and a significant reduction of greenhouse gases until 2050. Among the proposed measures to reach these targets, the policy documents highlighted cuttings in ship emissions and mode shifts from the road towards rail and water transport.

An essential role in the realisation of the GTC concept was dedicated to the BSR due to the role of the Baltic Sea as a Northern logistics hub and the importance of multimodal transport solutions. Already in 2008 the first green transportation initiatives started in BSR, and one outstanding EU initiative has to be mentioned, namely the «East-West Transport Corridor (EWTC)» realises an inter-modal green transport corridor between the South Baltic Sea and the Black Sea Region by using a shuttle train that links Klaipeda in Lithuania via Kyiv with llyichevsk in Ukraine in 55h (Figure 1).

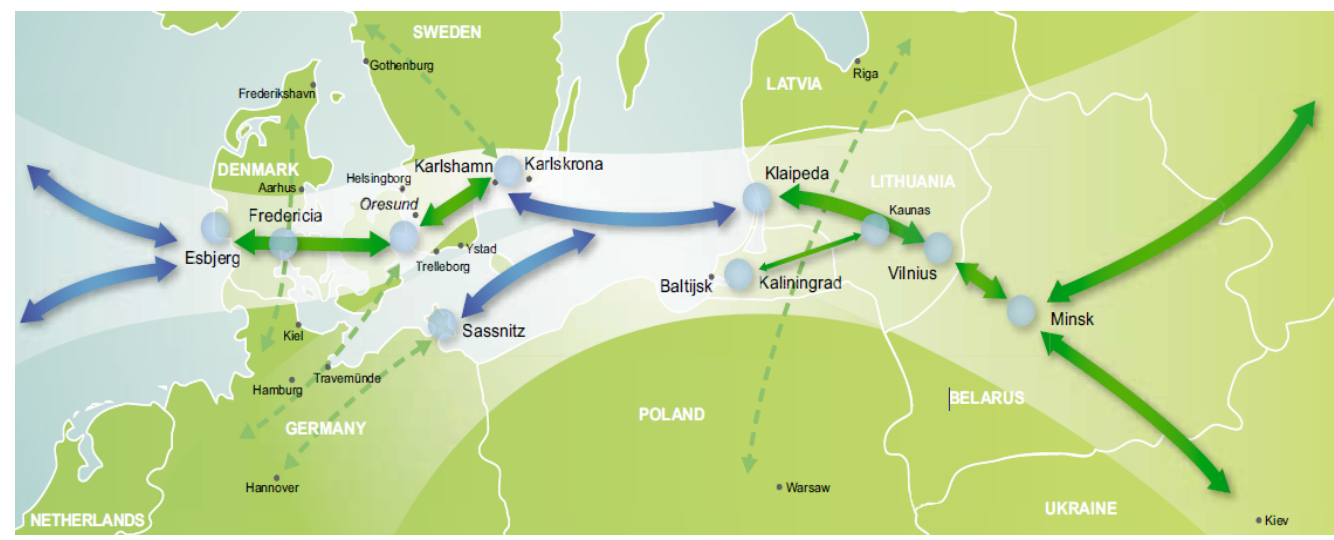

Figure 1. East-West Transport Corridor

Source: EWTC Association (http://www.ewtcassociation.net/)

The EWTC initiative represents an awarded GTC implementation, and during the project time, a GTC manual fixed for the first time objectives and requirements for GTC on the EU level (EWTC2, 2012). Furthermore, the EWTC initiative considered governance aspects for GTC green, and by linking Sweden, Lithuania, Belarus and Ukraine, the corridor manual also addressed management questions concerning transnational cluster and ownership structures that are still affecting the ongoing scientific discussions on green transport corridors (Figure 2).

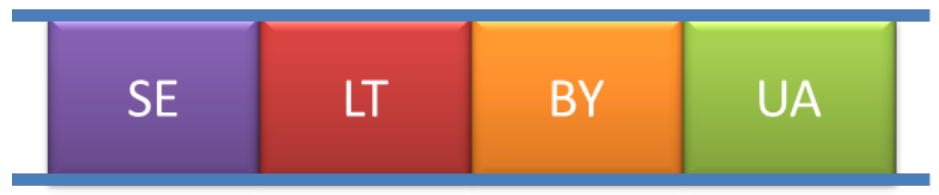

Figure 2. Green transport corridor as a transnational service cluster

Source: developed by the author

Figure 2 highlights already a couple of exciting questions arising with green corridors. The first topic is related to intercultural issues since different business cultures, different business models and different 
legal systems have to be harmonised. Another critical issue is related to multi-level governance of green corridors due to different objectives and interests of the complex set of GTC stakeholders.

Literature Review. The frame conditions of these GTCs, especially the corporatism and the transparency, feature new and uncharacteristic properties for the logistics sector, which partially contradict traditional business structures. Innovative blockchain-based technology - especially in the form of Smart Contracts - could furthermore facilitate the implementation of collaborative governance structures of GTC, but also of common-pool resources in general. Philipp et al. (2019) investigated the impact of blockchain technology and smart contracts to maritime supply chains and detected significant cost reductions as well as improvement potential in entrepreneurial collaboration.

The management and allocation of common-pool resources are discussed within logistics in the context of supply chain management (SCM), representing cross-company business processes within system innovation strategies (Jacobs \& Chase, 2014; Prokopenko, Omelyanenko \& Tirto, 2019). The coordination and optimisation of downstream flows of materials and upstream flows of information and finance of a supply chain represent a challenging task due to complex and distributed structures of stakeholder and inter-company business processes. With the growing importance of Industry 4.0, the traditional SCM topics are mapped into the sphere of smart manufacturing and logistics so that the SCM challenges are getting smarter, more fragmented and distributed and new concepts like self-organising, fractal structures, M2M systems as well as networked cyber-physical systems dominating the scientific discussion (Olaniyi \& Reidolf, 2015; Hoffmann \& Prause, 2018). These new smart SCM structures strengthen the part of distributed and commonly used resources with supply chains together with questions evoking governance and management issues.

Common-pool resources represent a core or key resource defining the inventory or stock variable that allows a limited quantity of units for exploitation, called the flow variable. The background problem of common-pool resource management is that the core resource has to be protected while the core resource is to be protected and fostered so that continuous exploitation safeguarded, i.e. the flow variable can be consumed. Ostrom $(1990,2009)$ identified eight principles for designing a stable common pool resource management that is defined in the following list:

- Clear definition of the nature of the common pool resource.

- Appropriation/provision of common resources adapted to local conditions.

- Collective-choice arrangements.

- Effective monitoring.

- A scale of graduated sanctions for resource appropriators.

- Mechanisms of conflict resolution that are cheap and of easy access.

- Self-determination of the community.

These original principles of Elinor Ostrom lied the ground for further research and have been slightly modified, expanded and adapted to unique features in order to integrate additional variables to master and model self-organised governance systems. Currently, scholars emphasise blockchain technologies for the facilitation of entrepreneurial collaboration and the management of common-pool resources in the context of networks and supply chains to solve and overcome obstacles related to fragmentation and distributed structures (Norta et al. 2014; Hoffmann et al. 2018).

Blockchain technology provides to interacting parties safe, permanent, and trusted transactions within a networked environment without a central authority by offering each participating party a local copy of the timestamped transaction ledger consisting of a list of encrypted blocks of transactions. In case of the appearance of a new block, the interacting parties agree in a consensus procedure upon a valid copy of the new block. By doing so, an accepted block of all parties is nearly impossible to change or to remove, i.e. a blockchain can replace a centralised register of transactions organised by a trusted authority (Udokwu et al. 2018). 
Methodology and research methods. This paper discusses the innovation potential in management and legal distribution of common-pool resources by smart contracts. The research is subdivided into three parts: The first part provides the theoretical background of governance models of common-pool resources at the example of GTC as well as for Smart Contracts and their relationship with cooperatives. Subsequently, empirical results from secondary data analysis, expert interviews, as well as case studies, are presented and discussed. Finally, the paper summarises these results and proposes respective implications.

a) Common-pool resource management at the example of GTCs.

GTCs represent socio-ecological transport systems that offer a limited number of logistics services and recourses to their users. The underlying infrastructure of the corridor, consisting of transport links, hubs, ICT - systems and other GTC resources, are used by the GTC stakeholders and have to be built, maintained and sustainably developed by investments. In this sense, the GTC resources enjoy properties of common-pool resources comprising the limited availability of the GTC resources, the open and fair access to the corridor resources in a transparent, democratic and cooperative environment.

In the case of GTC, the core resources consist of transport capacities and available services which are monitored by the GTC dashboard and the enabling and operating criteria (Hunke \& Prause, 2013). Scientists have advocated both state control as well as privatisation of resources, but in general, neither the state nor the markets have been successful in managing common-pool resources. Ostrom concluded that common pool resources could be managed successfully and sustainably by their users in the form of self-organisation, without state control or privatisation. This self-organised management of common-pool resources requires a multi-level approach, comprising an operative, a collective and a constitutional level necessary for the users to keep cooperation and self-organisation (Ostrom 1990, 2009). These principles can be transferred to GTC governance and implemented by blockchain technology (Prause, 2018; Philipp et al., 2019).

Even though the different GTC initiatives vary significantly in their interpretations of green transportation, there also exist common topics that are recognised by all GTC initiatives. First, "comodality» enables the choice of environmentally friendly transport along the transport route, since reduced emissions represent one of the apparent objectives of greener transportation. Secondly, essential success factors for green transport consist of all cases of adequate, and high performing trans-shipment facilities, innovative transport units and vehicles together with advanced ITS applications. These elements can be considered as base components of GTC since customers expect beyond environmental friendliness also economic advantages of the corridor used in the form of cost and time savings (Hunke \& Prause 2013).

However, the typical characteristics of GTC comprise additional topics, namely entrepreneurial growth and cluster development, representing two other essential issues which are attributed to GTC and which have been in the centre of nearly all GTC projects. Other properties that are located in the intersection of all GTC initiatives are linked to fair and non-discriminatory access to corridors and their trans-shipment facilities. Prause and Hoffmann (2017) studied cooperative business structures for GTCs by analysing how far collaborative concepts are contained in the GTC concept, and to what extent cooperative governance and ownership structures are appropriate concepts for the successful management of GTC.

b) Blockchain and Smart Contracts.

Blockchain technology is able to realise a decentralised network of trust without a third party or intermediary. This decentralised character of blockchains can facilitate smaller, independent entrepreneurs and SMEs competitiveness and efficiency, enabled through the improved information accessibility, reduced risks and layers of intermediaries, and thus declining intermediary and transaction costs. Hence, this technology bears the potential to foster entrepreneurial collaborations in logistics networks and supply chains across international borders. Hence, blockchain technology at first glance 
exhibits some unique features or characteristics, which at the same time, represent the critical advantages compared to other respective information technologies (Philipp et al., 2019):

1) decentralisation;

2) transparency and audit (through tamper-proof process history);

3) data integrity, security and immutability.

Smart contracts enable parties to automatically execute an obligation once triggered by an oracle, i.e. one transaction effects another transaction (for details see Norta 2017). Supply chains are characterised by the distribution of all essential data about parties (i.e. supplier and recipient), goods and conditions of delivery over the chain's databases. The sale of a product or the provision of services can be embedded as a transaction in the meta-text of a smart contract, which can be cryptographically signed by seller and buyer. Once the smart contract has been activated, transfer of corresponding funds and rights is automatically executed according to the agreed conditions (e.g. documentation, taxes or quality checks). In other words, smart contracts provide a non-falsifiable tool guaranteeing the execution of collaborative, entrepreneurial processes. $S$ smart contract is technically employed via formal language tools as eSourcing Markup Language (eSML) to «specify possible interactions and contracts and to enforce the agreements reached in distributed systems with low transaction costs in a standardised way» (Norta et al. 2014, 2015, Norta 2017).

Results. One of the main advantages of smart contracts is that they make the involvement of third parties (e.g. brokers) superfluous. Current research «tackles essential challenges in smart SCM by using these technologies» (Hofmann et al. 2018), coming to the interim result that in general, blockchain technology and smart contracts can provide suitable concepts for an efficient reform of collaborative business processes - including supply chains.

However, smart contracts and blockchain technology do not only provide potentials of cost reductions or to optimise the flow of goods in supply chains. It can as well support the integration of SMEs into crossorganisational business processes, as the access of SMEs to supply chains can be considerably facilitated once the IT-environment is opened and harmonised. This aspect is even more crucial as at present the branch is marked by monopolist structures; supply chains and their underlying infrastructure - including the IT-systems - are controlled by the «big players». This constellation creates high entry barriers to entrepreneurs and SMEs (Prause \& Hoffmann 2017). Besides, these established structures discourage process innovation, as third parties providing the much-needed standardisation are not interested in any reforms depriving them of their business models. However, as Phillip et al. pointed out, «blockchain technology bears the potential to break these monopolies and enables these processes to be executed in a distributed way without the need of central authorities, i.e. smart contracts and blockchain technology can facilitate and improve the implementation of collaborative business structures for sustainable entrepreneurial activities in smart supply chains» (Philipp et al., 2019).

Case study: GTC management by Smart-Contract steered SCEs. A key element for organising and managing open-pool resources is the creation and implementation of integrated ICT-system. Even though there is no general prototype for the final structure of such a comprehensive system, some cornerstones of such ICT systems have been established e.g. for green corridors, which rely on an open architecture and use standards and realise green and democratic models for efficient multimodal logistics markets.

However, these necessary functionalities are representing the more technical part of the requirements that have to be fulfilled by an integrated ICT-system. The more challenging task is to realise the legal, organisational and political framework for such system architecture. According to the results of green corridor initiatives from BSR - which can be extended in its principal and non-transport relate concepts to common-pool resource management in general, - integrated ICT-systems have to meet the following system requirements:

- Open architecture. 
- It was oriented on standards.

- Focus on interoperability and co-modality.

- Independent of technology.

- Endorsed and adopted by significant freight ICT-systems providers and logistics operators.

- Support the European transport and logistics system to be more efficient and environmentalfriendly.

- Create a fair and balanced transport spot market within the corridors, enabling market leaders and SMEs to interact at a low cost.

In legal terms, the first challenge for such ICT-systems is the choice of an appropriate cooperative model for GTC.

The mentioned frame requirements have to be reflected in the management structures and asset distribution models of GTCs. The choice among available legal structures for a corridor should be made among EU legal forms since all considered green corridor projects are touching more than one EU member state. While in general possible European legal forms are Non-profit organisations (NGO) or associations, European Economic Interest Groupings (EEIG), European Cooperative Society (SCE), European Private Company (SPE) and the European Society (SE),

The advantage of EU based corridor management solutions are the underlying common legal regulation frameworks for business models defining value propositions to clients of the green transport corridor, and to stakeholders to use and support the shared assets and solutions of the corridor (Osterwalder 2004). NGOs and other non-corporate forms of organisation do not provide sufficiently consistent and pan-European recognition; therefore, instruments set up by European regulations are preferable.

These considerations also apply to the organisation of shared resources, as in the integrated green corridor ICT - system «Information Broker» of the EWTC2 - project. In the case of the ownership of the Information Broker, the main task is about selecting and organising owners for the ICT-system to ensure maximum value for the vision of the East-West Transport Corridor. However, the requirements for an ownership model and the choice of the legal form depend on the type of owner. While small businesses concentrate primarily on taxation, risk management and access to GTC markets, companies with multiple owners or NGO's may prioritise other commercial and environmental goals differently.

The choice of a suitable legal business entity might be further complicated by the need for legal, social, competitive and political considerations. Just as national cooperatives, SCEs are also member-owned and member-managed entities that accumulate benefits for its members. A company or institution that wants to become a member of an SCE applies for membership and buys a share, to return various types of value to the cooperative, not only to benefit from it but also participating in the cooperative decision-making process. SCEs usually provide some products and services to its members free. In the Information Broker membership, these standard (free) services could comprise: access to information and application of programming interface (API); (legal) document templates; system service and support; seminars and newsletters; other services like information brokerage and consulting services.

A possible solution for the demands of the Information broker can be found in the structures of the SCE (Prause \& Hoffmann 2017). The structure of the SCE generally corresponds with the construction of the SE, including the rule «one-member-one-vote» applying for SCEs, which makes it complies with the standard and stable frame conditions of GTC, mainly because the value of member shares can vary among the members allowing economically more influential members to take more significant financial shares than smaller members. Since each cooperative has a fixed mission, the cooperative can develop the GTC towards a shared vision. Any profit generated by the Information Broker can be distributed as dividends among the members or reinvested in the financial stability or value of the SCE for its members since the member capital is the preferred source of financing in a cooperative. Other sources include bank 
loans and grants from governments and non-profit organisations. Therefore, the SCE would make sure that various benefits are implemented in a structured manner, in line with the cooperative business objectives and vision for ICT/ITS in the East-West Transport Corridor. This procedure affects the Information Broker's strategy will support reaching the East-West Transport corridor's objectives, but an SCE is generally threatened to realise slow decision-making processes. Thus, a democratic business model and decision-making procedures require strong communication policies, active involvement from members and can be time-consuming and more costly than in other legal forms. Thus, GTC entities in the form of SCEs are capable of guaranteeing financial stability and reflecting cooperative governance structures, as well as underlining the respective strategies and vision of GTC entities. The involvement of the public sector in the relevant countries retains the focus on both the public good and business benefits for corridor stakeholders at the same time.

The second legal challenge arises when assets have to be distributed within the cooperative in a fair and legal-specific procedure. The legal nature of smart contracts is at a closer look usually much less legal than anticipated (Hoffmann, 2019b) since a «Smart Contract» - as defined by Szabo (1997) as «a set of promises, specified in digital form, including protocols within which the parties perform on these promises» - is not necessarily a contract. In the most legal system, a contract is formed by two usually form-free corresponding declarations of intending which sufficiently entail all essential negotiations, on parties to the contract, the object of the agreement, modes of performance etc. The smart contract, on the other hand, is simply a software-based log of actions which may have legal significance (in that case, it protocols a declaration of intent) and which - if respectively programmed - effectuates an additional transaction (Hoffmann 2019a). Beyond that, many legal effects - e.g. of void declarations of intent issued via a smart contract - do not necessarily differ from traditional ways of performance (Hoffmann 2019a). From a business management perspective, «the main reason for relying on smart contracts applications are transparency and trust - which also represent necessary ingredients of Industry 4.0 aiming to develop cyber-physical systems and dynamic production networks to achieve flexible and open value chains in the manufacturing of complex mass customisation products in a small series up to lot size 1. In that context, smart contracts add the concept of self-performance to the already well-known Industry 4.0 properties self-organising and self-optimising perfecting the needed characteristics for coordinating smart manufacturing and logistics systems based on fractals, networked CPS and M2M networks» (Prause \& Boevsky 2019).

From a legal perspective, it is questionable whether the use of smart contracts - here, especially in the form of follow-up contracts - in order to distribute access to resources in terms of both general common-pool resources. GTCs implies an added value automatically for legal certainty and fair balance among different forms and degrees of access granted to different members of the cooperative. The distribution itself is performed immediately and without the possibility of later interference/reversion (except by the initiation of a hard fork, which seems less probable in complex distribution architectures). The prior criteria of how and to which degree grant access to resources are instead set up by the provider of the smart contract code than by the individual cooperative member, who only in rare cases will have coded the criteria triggering a transaction himself. Moreover, in contrast to other information technology, a cooperative member may use in daily practice. Also, the provider of the smart contract software will usually have written the respective smart contract instead by composing modules of smart contract tools into appropriate smart contracts than by bespoken coding.

Moreover, as the combination of Smart Contracts with software agents would fully uncover the potential of Smart Contracts, questions of non-transparent accountability of declarations of intent may even become more virulent in practice once algorithm-based decisions would be immediately performed. These aspects may be taken into account by major companies equipped with the respective know-how and critical mass of expertise in handling the combination of algorithm-based decisions performed by 
smart contracts - as in port management or other major logistic hubs (Metzger et al. 2019), actors may be less experienced in typical cooperative set-ups, where cooperative members are often composed of SMEs. As the system-immanent pseudonymity of smart contracts can considerably hinder litigation on cases of incorrect performance, change of circumstances or unduly induced contracts, smart contracts fall considerably short on the protection of weaker parties (de Filippi 2019) - which in common-source resource distribution tasks as illustrated here at the example of GTCs can be to a decisive detriment of the cooperative members. Research on the use of blockchain and worker cooperatives came to similar results for the management labour-managed firms (Mannan 2018), stating that «it is necessary to challenge and grapple with the complexity of these governance structures in which corporate governanceby-design is sought, as it potentially embeds power structures in new and unexpected ways», as the complexity of GTCs may supersede those of labour-managed firms by far.

Conclusions. While it is less controversial that the frame conditions for the utilisation of common-pool resources in general and GTCs mainly must be based on self-organisation and cooperative governance models, the question whether smart contracts or other blockchain-based architectures are a viable means for the legal distribution of access to limited resources, and if so, whether such an approach provides for fair and foreseeable results also for the use in cooperatives as the SCE. Smart contracts as such may provide much use in terms of openness, known-temporality and reliability of envisaged transactions. However, the question remains to which degree these specific transactions can still be envisaged - i.e. foreseen - at all in complex distribution situations where the scope of users does not consist of experienced and well-equipped companies having the capacity and training to navigate in these systems, but rather by SMEs. In this regard, fairness and non-discriminatory access to corridor resources cannot be guaranteed by the use of smart contracts alone. The smart contracting and blockchain technology is generally able to facilitate the creation of cooperative governance models and collaborative business structures for GTC as well as for their underlying common-pool resources, their usage for cooperatives as, e.g. GTC-setups - should take account interests of weaker parties, for instance by providing a certified pool of smart contract modules designed for the fair and foreseeable distribution of resource access or specialised training for participating members.

Author Contributions: Conceptualisation, methodology, software, validation, formal analysis, resources, data curation - G.P., T.H.

\section{References}

COM. (2007). Communication from the Commission: Freight Transport Logistics Action Plan. Commission of European Communities. Brussels, 18.10.2007. Retrieved from http://aei.pitt.edu/96122/1/COM (2007) 607 final.pdf

COM. (2011). Roadmap to a Single European Transport Area - Towards a competitive and resource efficient transport system. Commission of European Communities. Brussels, 28.03.2011. Retrieved from https:/leurlex.europa.eu/LexUriServ/LexUriServ.do?uri=COM:2011:0144:FIN:EN:PDF

De Filippi, P., \& Wright, A. (2019). Blockchain and the Law. The Rule of Code, Harvard University Press, ISBN 9780674241596

EWTC 2. (2012). Green Corridor Manual-Task 3B of the EWTC II project. Femern (2019). Retrieved from https://femern.com/en

Hoffmann, T. (2019a). Smart Contracts and Void Declarations of Intent. Cappiello, C.; Ruiz Carmona, M. (Ed.). Information Systems

Engineering in Responsible Information Systems (168-175). Heidelberg: Springer International Publishing. [CrossRef]

Hoffmann, T., \& Prause, G. (2018). On the regulatory framework for last-mile delivery robots. Machines, 6(3) (33). [Google Scholar] [CrossRef]

Hoffmann, T., \& Skwarek, V. (2019b). Blockchain, Smart Contracts und Recht Smart Contracts als Risiko für Informatiker. Informatik Spektrum, 42 (3), 197-204. [Google Scholar] [CrossRef]

Hofmann, E., Strewe, U., \& Bosia, N. (2018). Supply Chain Finance and Blockchain Technology, Springer. [Google Scholar]

Hunke, K., \& Prause, G. (2013). Management of green corridor performance. Transport and Telecommunication, 14(4), 292-299. [Google Scholar] [CrossRef]

Jacobs, F. R., Chase, R. B. (2014). Operations and Supply Chain Management (14th edition). New York, NY McGrawHill. [Google Scholoar]

Mannan, M. (2018). Fostering Worker Cooperatives with Blockchain Technology: Lessons from the Colony Project. Erasmus L. Review, 3, 190. [Google Scholar] [CrossRef] 
Metzger, A., Neubauer, A., Bohn, P., \& Pohl, K. (2019). proactive process adaptation using deep learning ensembles. In: Giorgini, P.; \& Weber, B., (eds), 31st Int'I Conference on Advanced Information Systems Engineering (CAiSE 2019), Rome, Springer.

Norta, A. (2016, November). Designing a smart-contract application layer for transacting decentralised autonomous organisations. In International Conference on Advances in Computing and Data Sciences (pp. 595-604). Springer, Singapore. [Google Scholar]

Norta, A., Grefen, P., \& Narendra, NC. (2014). A reference architecture for managing dynamic inter-organisational business processes. Data \& Knowledge Engineering, 91, 52-89. [Google Scholar] [CrossRef]

Norta, A., Ma, L., Duan, Y., Rull, A., Kolvart, M., \& Taveter, K. (2015). eContractual choreography-language properties towards cross-organisational business collaboration. Journal of Internet Services and Applications, 6(1), 8. [Google Scholar] [CrossRef]

Olaniyi, EO, \& Reidolf, M. (2015). Organisational innovation strategies in the context of smart specialisation. Journal Security and Sustainability /ssues, 5. [Google Scholar]

Osterwalder, A. (2004). The business model ontology a proposition in a design science approach (Doctoral dissertation, Universite de Lausanne, Faculte des hautes etudes commerciales). [Google Scholar]

Ostrom, E. (1990). Governing the commons: The evolution of institutions for collective action, Cambridge university press. [Google $\underline{\text { Scholar] }}$

Ostrom, E. (2009). A general framework for analysing sustainability of social-ecological systems. Science, 325(5939), 419-422 [Google Scholar] [CrossRef]

Philipp, R., Prause, G., \& Gerlitz, L. (2019). Blockchain and Smart Contracts for Entrepreneurial Collaboration in Maritime Supply Chains. Transport and Telecommunication Journal, 20(4), 365-378. [Google Scholar] [CrossRef]

Prause, G., \& Boevsky, I. (2019). Smart contracts for smart rural supply chains. Bulgarian Journal of Agricultural Science, 25(3), 454-463. [Google Scholar]

Prause, G., \& Hoffmann, T. (2017). Cooperative Business Structures for Green Transport Corridors. Baltic Journal of European Studies, 7(2), 3-27. [Google Scholar]

Prokopenko, O., Omelyanenko, V., \& Tirto, T. (2019). Security issues of system innovation strategies. In Web of Conferences (Vol. 65, p. 03006). EDP Sciences. [Google Scholar] [CrossRef]

Szabo, N. (1997). Formalising and securing relationships on public networks. First Monday 2(9). [Google Scholar]

Udokwu, C., Kormiltsyny, A., Thangalimodziz, K., \& Norta, A. (2018). The state of the art for blockchain-enabled smart-contract applications in the organisation.In 2018 /vannikov Ispras Open Conference (ISPRAS) (pp. 137-144). IEEE. [Google Scholar] [CrossRef]

Праузе Гуннар, Dr.Sc., професор, Талліннський технологічний університет (Естонія); Бізнес-Школа Вісмара, Університет вісмара (Німеччина);

Хофффманн Томас, Dr.Sc., професор, Талліннський технологічний університет (Естонія).

Інноваційне управління спільними ресурсами за допомогою смарт-контрактів

у статі авторами проаналізовано особливості новітніх методів управління спільними ресурсами, на прикладі зелених транспортних коридорів ЄС. На основі результатів узагальнення досвіду краї ЄС встановлено, що зелені транспортні коридори $\epsilon$ «стійкими логістичними рішеннями для перевезення вантажів із спільними ресурсами мультимодальними транзитними шляхами з їх концентрацією між основними транспортними вузлами». Незважаючи на те, що концепція зелених транспортних коридорів функціонує упрактиці країн ЄС тривалий час наразі залишається низка питань, що потребують подальших досліджень, а саме: інноваційні технологіїуправління зеленими транспортними коридорами; маркетингові інструменти в управлінні зеленими транспортними коридорами. Авторами систематизовано науковий доробок щодо впливу впровадження системи смартконтрактів та блокчейн-технологій на ефективність управління зеленими транспортними коридорами. При цьому проаналізовано перспективи та загрози застосовування смарт-контрактів для забезпечення правової безпеки при управлінні та розподілу прав на управління спільними ресурсами. Авторами визначено, що смарт-контракти можуть розглядатися як комп'ютеризовані протоколи транзакцій для виконання базових юридичних договорів щодо зниження трансакційних витрат за допомогою відстежуваних та незворотних транзакцій блокчейн-технологією. Результати дослідження підтвердили гіпотезу про високий потенціал смарт-контрактів при зміцненні кооперативних бізнес-структур та підприємницькій колоборації міжорганізаційних бізнес-процесів. У статті визначено, що використання смарт-контрактів, з метою розповсюдження доступу до спільних ресурсів, сприяє правовій визначеності та справедливому співвідношенню інтересів залежно від форми та рівня доступу учасників до зелених транспортних коридорів. Однак, у випадку неналежного виконання обов'язків та зміни зовнішніх факторів, смартконтракти не забезпечують відповідного захисту аутсайдерів-учасників зеленого транспортного коридору. Результати аналізу можливостей та загроз використання смарт-контрактів підтвердили іх значну роль у розповсюдженні доступу до ресурсів спільної власності.

Ключові слова: ресурси спільної власності, спільне управління, блокчейн, смарт-контракти, зелені транспортні коридори.

Manuscript received: 03.12.2019.

(C) The author(s) 2020. This article is published with open access at Sumy State University. 